\title{
Article \\ On Landscape Patterns in Typical Mountainous Counties Middle Reaches of the Yangtze River in China
}

\author{
Yang Yi ${ }^{1,2,3,4}\left(\mathbb{D}\right.$, Mingchang Shi ${ }^{2, *}$, Chunjiang Liu ${ }^{3,4}$, Hongzhang Kang ${ }^{3,4}$ and Bin Wang ${ }^{2, *}(\mathbb{D}$ \\ 1 Shanghai Engineering Research Center of Landscaping on Challenging Urban Sites, Shanghai Academy of \\ Landscape Architecture Science and Planning, 899 Longwu Road, Xuhui District, Shanghai 200232, China; \\ yiyang0307@sjtu.edu.cn \\ 2 Beijing Engineering Research Center of Soil and Water Conservation, Beijing Forestry University, \\ Beijing 100083, China \\ 3 School of Agriculture and Biology, Shanghai Jiao Tong University, Shanghai 200240, China; \\ chjliu@sjtu.edu.cn (C.L.); kanghz@sjtu.edu.cn (H.K.) \\ 4 Shanghai Urban Forest Ecosystem Research Station, State Forestry Administration, Shanghai 200240, China \\ * Correspondence: shimc@dtgis.com (M.S.); wangbin1836@bjfu.edu.cn (B.W.)
}

check for updates

Citation: Yi, Y.; Shi, M.; Liu, C.; Kang, H.; Wang, B. On Landscape Patterns in Typical Mountainous Counties Middle Reaches of the Yangtze River in China. Int. J. Environ. Res. Public Health 2021, 18, 4000. https:// doi.org/10.3390/ijerph18084000

Academic Editor: Paul Tchounwou

Received: 12 March 2021

Accepted: 8 April 2021

Published: 10 April 2021

Publisher's Note: MDPI stays neutra with regard to jurisdictional claims in published maps and institutional affiliations.

Copyright: (c) 2021 by the authors. Licensee MDPI, Basel, Switzerland. This article is an open access article distributed under the terms and conditions of the Creative Commons Attribution (CC BY) license (https:// creativecommons.org/licenses/by/ $4.0 /)$.

\begin{abstract}
The landscape patterns of plantations (PT) are the results of human disturbances on local vegetation, and in turn, differ greatly from natural forests (NF), since the patterns strongly influence the natural circulation of material and energy. There is a need to understand the differences of landscape patterns between PT and NF, to establish a near natural afforestation strategy. This study chose three typical silvicultural counties in the middle reaches of the Yangtze River as the research areas and compared the landscape patterns of NF and PT, with other land use types (grassland, GL; cropland, CL; shrubland, SL; orchard, OR; built-up land, BUL; bare land, BL; and water bodies, WB). The results revealed that the areas of PT accounted for $7.67 \%, 12.05 \%$, and $18.97 \%$ of three counties, bigger than GL, OC, BUL, BL, and WB, as one of main land use types. The landscape patterns of PT (mean patch size between 2.06 to $6.05 \mathrm{ha}$ ) were more fragmented than NF (mean patch size between 5.83 to $53.91 \mathrm{ha}$ ). NF areas increased along the relative altitude gradient, from 0 to $2500 \mathrm{~m}$, while PT areas peaked from 100-1000 $\mathrm{m}$. The higher the altitude, the more typical the zonal distribution of PT, the more aggregated the NF. NF had significant negative correlations with BL, BUL, CL, PT, GL, and OC, which suggest that human activities had seriously interfered with NF. Although PT as an ecological protection strategy was increasing, the landscape patterns of PT were obviously different from NF. This may affect the material energy flow in the ecological environment. The results in the present study have great implications in the other regions in China and the relevant parts of the world where natural forests were heavily disturbed.
\end{abstract}

Keywords: plantations; natural forests; landscape patterns; mountainous areas; Yangtze River

\section{Introduction}

The patterns of natural landscape are primarily modified by anthropogenic disturbances in many regions of the world, although they are influenced by diverse factors [1-3]. Such patterns have profound consequences in the ecosystem and the products that they provide [4,5]. Most of landscape changes have occurred as a result of change in land use types. Land use types are defined by their anthropogenic use, such as forests, cropland, built-up land, etc. [6,7]. When land use types change, the structure and function of landscapes also change.

Using landscape indicators to define the landscape and a consideration of multiple spatial scales are the basis for understanding the complexity of space [8]. The landscape often shows different patterns at different spatial scales. An analysis from a single-scale usually ignores the details [9]. Therefore, it is necessary to select appropriate landscape indicators from multiple scales to analyze landscape patterns. Indicators can be categorized 
according to whether their responses are consistent or not, and there are differences in responses among different research scales $[10,11]$. In this context, with the same spatial scope and roughly the same proportion of land use types, the landscape features between different regions were representative and could represent the landscape patterns features of other regions with the same level of development [12,13].

Mountainous areas account for about one-quarter of the total land areas of the world. It has one-tenth of the world's population and provides more than half of the world's goods and services [14]. Once China sacrificed its ecological environment in pursuit of economic development, the natural forests in mountainous areas suffered a lot of damage [15-17]. Between 2010 and 2015, the world's natural forest areas lost 6.5 million hectares a year, while plantations grew at a rate of more than 3 million hectares a year [18]. In this context, the "Middle Yangtze River Shelter Forest System" has been established in the Yangtze River basin [19]. Many studies have proved that the biodiversity and ecosystem services of plantations are lower than those of natural forests [20,21]. In fact, the fragmentation of forest landscape has a negative impact on biodiversity and ecosystem function [22,23], but there are few articles comparing the patterns differences between plantations and natural forests.

For this paper, three silvicultural counties, Shaoyang in Hunan Province, Shicheng in Jiangxi Province, and Zhushan in Hubei Province, were selected as the study sites. The three counties belong to typical mountainous areas and basically represented the landscape patterns of plantations and natural forests in the middle reaches of the Yangtze River. Through a multi-scale study, this study is conducted to compare the differences of landscape patterns between plantations and natural forests, and explore the impact of human activities on forests. The objectives of this study are (1) to quantify land use composition and landscape patterns in mountainous areas, (2) to examine characteristics of plantations and natural forests in mountainous areas, and (3) to discuss the relationship of forests (plantations and natural forests) distributions with other land use types. In addition, it should be noted that there were many abbreviations in this paper, thus please refer to Appendix A.

\section{Materials and Methods}

\subsection{Study Area}

The study areas included three typical counties, respectively, Shaoyang county (SY) in Hunan Province $\left(110^{\circ} 59^{\prime}-110^{\circ} 40^{\prime}\right.$ E, $\left.26^{\circ} 40^{\prime}-27^{\circ} 06^{\prime} \mathrm{N}\right)$, Zhushan county (ZS) in Hubei Province $\left(109^{\circ} 32^{\prime}-110^{\circ} 25^{\prime} \mathrm{E}, 31^{\circ} 30^{\prime}-32^{\circ} 37^{\prime} \mathrm{N}\right)$, and Shicheng county (SC) in Jiangxi Province $\left(116^{\circ} 05^{\prime}-116^{\circ} 38^{\prime}\right.$ E, $25^{\circ} 57^{\prime}-26^{\circ} 36^{\prime}$ N) (Figure 1). SY belongs to a mid-subtropical monsoon humid climate area, with an annual precipitation of $1314.2 \mathrm{~mm}$ and annual average temperature of $17.8^{\circ} \mathrm{C}$ [24,25]. ZS belongs to a subtropical continental monsoon climate, with an average annual precipitation of $905.2 \mathrm{~mm}$, and median annual temperature of $15.6^{\circ} \mathrm{C}$ [26]. SC belongs to a humid subtropical monsoon climate, with an average annual rainfall of $1757 \mathrm{~mm}$, and annual average temperature of $18.5^{\circ} \mathrm{C}[27,28]$. The three counties all have a common feature, that is, they are located in the low hilly areas in the middle reaches of the Yangtze River, and are typical counties of planted forests. Taking these three counties as research areas, this study can preliminarily estimate the overall characteristics of landscape pattern, especially the characteristics of plantations and natural forests in the afforestation areas of the middle reaches of the Yangtze River in China.

These three counties reside within typical mountainous areas, being far away from provincial capital cities and mid-sized cities in the Yangtze River Economic Zone, and are the key implementation areas of the "Middle Yangtze River Shelter Forest System", which is a high proportion of plantations in the landscape. These plantations typically exist in the form of pure stands, and the understory vegetation is relatively homogeneous. The plantation species mainly include Chinese fir, Masson pine, and bamboo (Figure 2a-c). The natural forests are broad-leaved forests mainly composed of Schima spp., Cinnamomum 
spp., and Quercus spp., etc. (Figure 2d-f). The three study areas possess the dual attributes of mountainous ecosystem vulnerability and underdevelopment of regional economies.
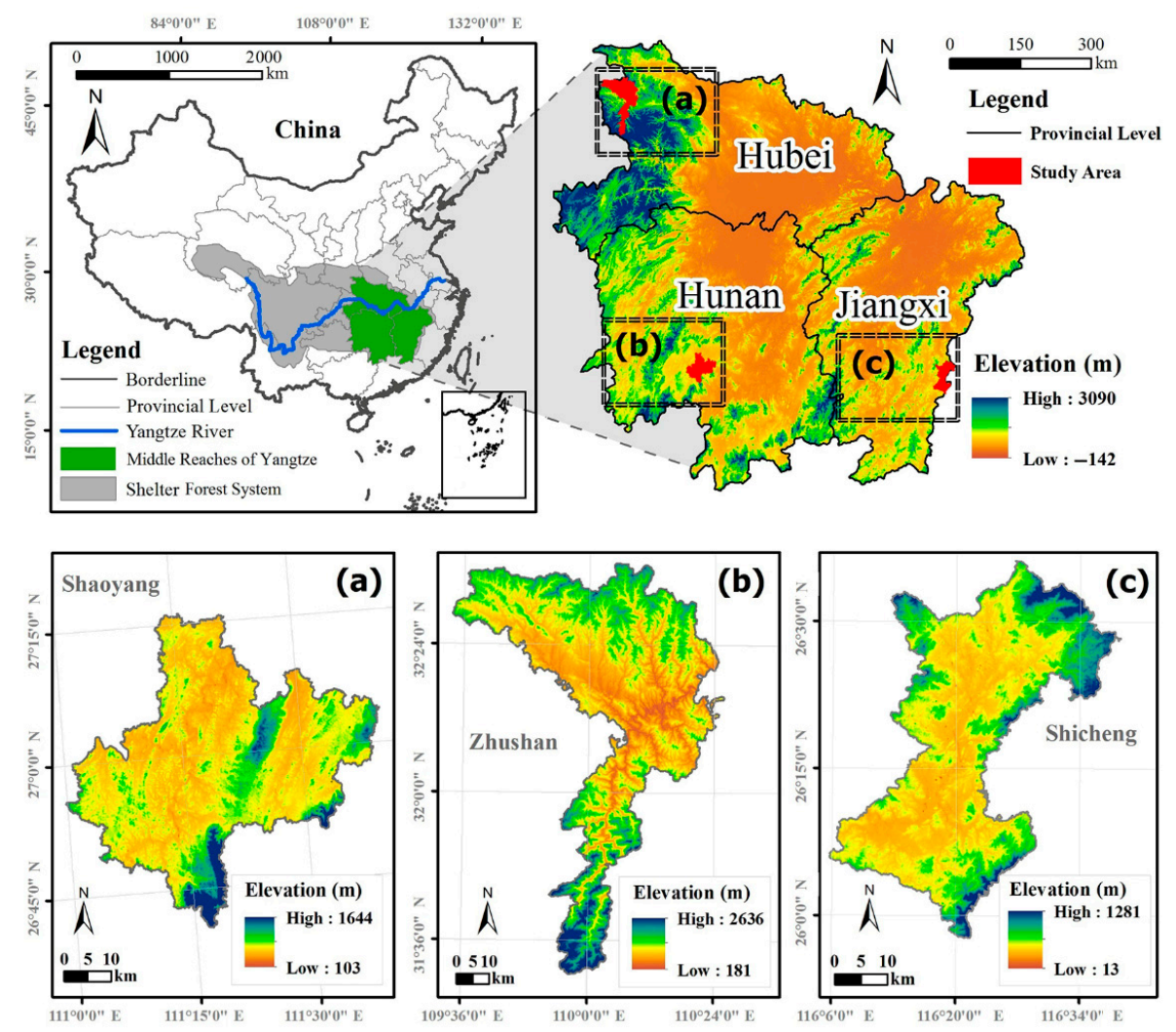

Figure 1. Locations of Shaoyang (SY) (a), Zhushan (ZS) (b), and Shicheng (SC) (c) counties in the middle reaches of the Yangtze River (MRYR).

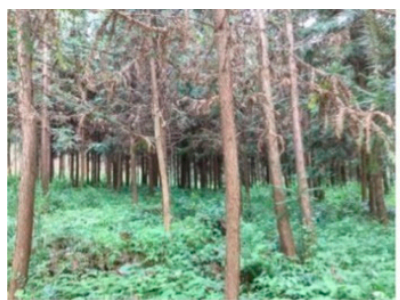

(a)

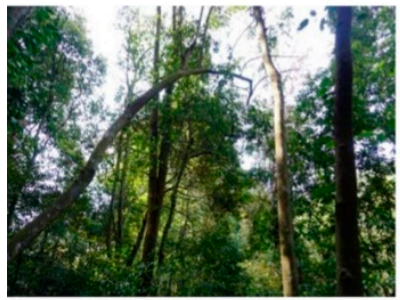

(d)

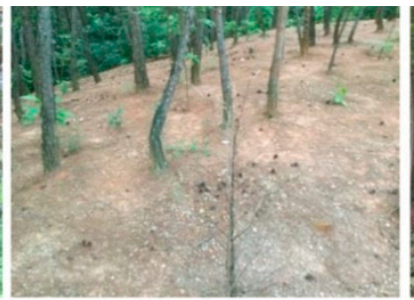

(b)

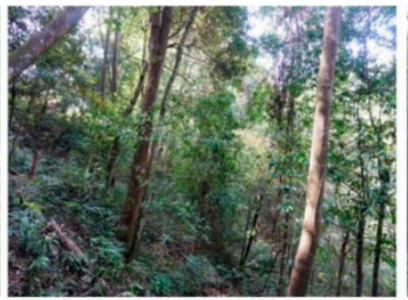

(e)

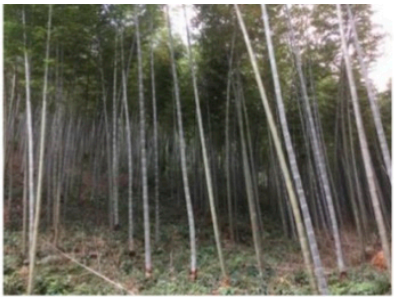

(c)

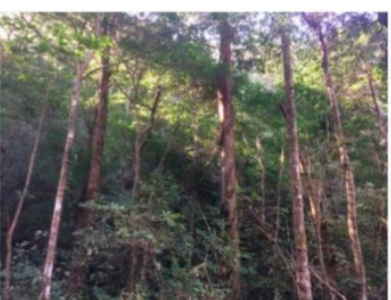

(f)

Figure 2. Vegetation characteristics in the study area; $(\mathbf{a}-\mathbf{c})$ plantation; $(\mathbf{d}-\mathbf{f})$ natural forests.

\subsection{Data Preprocessing}

The data from 2009 and 2013 Landsat TM/OLI remote sensing images were used in this study, covering study areas in three typical counties (SY, ZS, and SC) [29,30]. The land use types in the study areas and China's land use classification system are referred for classification. Considering the artificial forest and natural forest, the texture structure 
of remote sensing image is quite different. Usually plantations present regular textures. Therefore, this study applied the grayscale co-occurrence matrix to calculate eight features (energy, contrast, entropy, uniformity, mean value, variance, non-similarity, and correlation) in the image texture features and added them into the spectrum as classification features. Then, the neural network method is used to divide land use into nine categories [31]. These areas include the grass (GL), farmland (CL), shrub (SL), orchard (OC), built-up area (BUL), bare land (BL), water (WB), plantation (PT), and natural forest (NF) (Table 1). Ninety samples were randomly selected for each county (270), with high resolution image inspection Google earth $(10 \times 10 \mathrm{~m})$ and the accuracy of interpretation, the overall accuracy, and kappa coefficient were $>80 \%$. All operations were performed using the ENVI 5.3 software.

Table 1. Land use types in the study area (based on the Yi and Chinese National Standard) [32,33].

\begin{tabular}{cc}
\hline Land Cover Types & Description \\
\hline Grassland (GL) & $\begin{array}{c}\text { Refers to growing herbaceous plants, including pasture or mainly pasture. } \\
\text { Refers to land for planting crops, including cultivated land, new open } \\
\text { wasteland, wheeled land, and crop fields so as to cultivate rice, lotus root, } \\
\text { and other aquatic crops. } \\
\text { Short woodlands and shrubs. }\end{array}$ \\
$\begin{array}{c}\text { Shrubland (SL) } \\
\text { Orchard (OC) }\end{array}$ & $\begin{array}{r}\text { Refers to many years of intensive planting of woody and herbaceous crops } \\
\text { for the intensive management of fruit, leaves, roots, stems, and juices. } \\
\text { All types of manmade structures: Residential, industrial, agricultural } \\
\text { commercial and services; transportation and utilities. }\end{array}$ \\
Built-up land (BUL) & $\begin{array}{r}\text { The surface is rock or gravel, bare soils, sand, and bare stone. } \\
\text { Bare land (BL) }\end{array}$
\end{tabular}

\subsection{Selected Pattern Metrics and Computing}

Mean patch size (MPS), percentage of landscape (PLAND), interspersion juxtaposition index (IJI), largest patch index (LPI), perimeter area fractal dimension (PAFRAC), and patch cohesion index (COHESION) were selected to characterize landscape patterns $[10,11]$. The significance of these landscape indicators re MPS: Measures the extent of landscape fragmentation; PLAND: Measures the proportion of landscape; IJI: Reflects typical zonal distribution; LPI: Reflects dominant patch; PAFRAC: Reflects the complexity of the patch shape; and COHESION: Reflects the degree of aggregation or extension of patches (Table 2).

Table 2. Description of landscape configuration metrics [10].

\begin{tabular}{|c|c|c|c|}
\hline Structural Category & Landscape Metrics & Abbreviation & Description \\
\hline \multirow[t]{3}{*}{ Area/Density } & Percentage of Landscape & PLAND & $\begin{array}{l}\text { Measures the percentage of } \\
\text { landscape }\end{array}$ \\
\hline & Largest Patch Index & LPI & Area of the largest patch \\
\hline & Mean Patch Area & MPS & $\begin{array}{l}\text { The average mean surface of } \\
\text { patches }\end{array}$ \\
\hline Shape & $\begin{array}{l}\text { Area-Weighted Mean Fractal } \\
\text { Dimension Index }\end{array}$ & PAFRAC & $\begin{array}{l}\text { Fractal dimension: Ratio of } \\
\text { perimeter per unit area. Increases as } \\
\text { patches become more irregular }\end{array}$ \\
\hline Isolation and Interspersion & $\begin{array}{l}\text { Interspersion Juxtaposition } \\
\text { Index }\end{array}$ & IJI & $\begin{array}{l}\text { Proximity of patches in each class. } \\
\text { High values correspond to } \\
\text { proportionate distribution of patch } \\
\text { type adjacencies }\end{array}$ \\
\hline Connectivity & Patch Cohesion Index & COHESION & $\begin{array}{l}\text { Increases as the patches of the } \\
\text { corresponding patch type become } \\
\text { less connected }\end{array}$ \\
\hline
\end{tabular}

The following equations calculate the MPS, PLAND, IJI, PAFRAC, and COHESION. All calculations were extracted from the FRAGSTATS 4.2 software manual.

$$
M P S_{i}=\sum_{j=1}^{n} \frac{a_{i j}}{n_{i}}
$$


where $i$ is the $i$ th land use type, $j$ is the $j$ th patch of the $i$ th land use type, $a_{i j}$ is the $j$ th patch area of the $i$ th land use type, and $n_{i}$ is the patch number of the $i$ th land use type.

$$
\operatorname{PLAND}_{i}=\frac{\sum_{j=1}^{n} a_{i j}}{A} \times 100 \%
$$

where $a_{i j}$ is the area of patch $i j$, and $A$ is the total landscape area, $0<P L A N D \leq 100 \%$.

$$
I J I=\frac{-\sum_{i=1}^{m} \sum_{k=i+1}^{m}\left[\left(\frac{e_{i k}}{E}\right) \cdot \ln \left(\frac{e_{i k}}{E}\right)\right]}{\ln (0.5[m(m-1)])}(100 \%)
$$

where $e_{i k}$ is the total length (m) of the edge in the landscape between patch types (classes) $i$ and $k$; $E$ is the total length $(\mathrm{m})$ of edge in the landscape, excluding outer boundary; and $m$ is the number of patch types (classes) that are present in the landscape, including the landscape border.

$$
L P I_{i}=\frac{\max _{i=1}^{n} a_{i}}{A} \times 100 \%
$$

where $a_{i j}$ is the area of patch $i$, and $A$ is the total landscape area, $0<L P I_{i} \leq 100 \%$.

$$
\text { PAFRAC }=\frac{\frac{2}{n_{i} \sum_{j=1}^{n}\left(\log p_{i j}-\log a_{i j}\right)-\sum_{i=1}^{n} p_{i} \sum_{i=1}^{n} a_{i}}}{n_{i} \log p_{i}{ }^{2}-\left(\sum_{i=1}^{n} \log p_{i}\right)^{2}}
$$

where $a_{i}$ is the area of patch $i\left(\mathrm{~m}^{2}\right), p_{i}$ is the perimeter of patch $i(\mathrm{~m}), n_{i}$ is the number of patches in the landscape of patch type $i, 1 \leq$ PAFRAC $\leq 2$.

$$
\text { COHESION }=\left[1-\frac{\sum_{i=1}^{m} \sum_{j=1}^{n} p_{i j}}{\sum_{i=1}^{m} \sum_{j=1}^{n} p_{i j} \sqrt{a_{i j}}}\right] \cdot\left[1-\frac{1}{\sqrt{Z}}\right]^{-1} \cdot(100 \%)
$$

where $p_{i j}$ is the perimeter of patch $i j$ in terms of number of cell surfaces, $a_{i j}$ is the area of patch $i j$ in terms of the number of cells, and $Z$ is the total number of cells in the landscape.

\subsection{Multi-Scales Analysis}

In order to make clear the characteristics and differences of the distribution of land use types, this study assessed the percentage of land use types in the research area by county, elevation, and watershed scales. According to the survey of forest resources planning and natural physiognomy in the study areas, the relative elevation of the study areas was segmented into five sub-regions, which included I (0-100 m), II (100-250 m), III (250-500 $\mathrm{m})$, IV (500-1000 m), and V (1000-2500 m). The current study analyzed the percentage of land use and the changes of landscape patterns from the five sub-regions, standardized the areas of land use in the three counties, and calculated the proportion of land use on average at different elevations, which better represented the characteristics of land use at specific elevations. The Soil and Water Assessment Tool (SWAT) and Digital Elevation Model (DEM) were used to divide the three research areas into several sub-basins. SY, ZS, and SC were divided in 35, 42, and 32 sub-basins, respectively. The percentage of different land use types in each sub-basin was calculated, and the correlation of different land use types at the watershed scale was analyzed.

\section{Results}

\subsection{Landscape Patterns of Land Use Types at the County Scale}

The main land use types of the three counties were NF and CL in 1990, which together accounted for more than $85 \%$ of the total land use types (Figure 3 and Table 3). From 1990 to 2013, the land use of the three counties changed significantly, among which NF, CL, PT, BUL, SL, and OC showed the same trend of change. Among them, the NF and CL in the three counties decreased significantly. The NF in SY, ZS, and SC decreased by $33.47 \%$, 
$51.86 \%$, and $34.75 \%$, respectively, and the CL decreased by $43.02 \%, 14.82 \%$, and $10.03 \%$. PT increased by $67.02 \%, 8.17 \%$, and $11.55 \%$, BUL increased by $5.31,18.40$, and 4.00 times. In addition, SL and OC also showed an increasing trend in the study period.
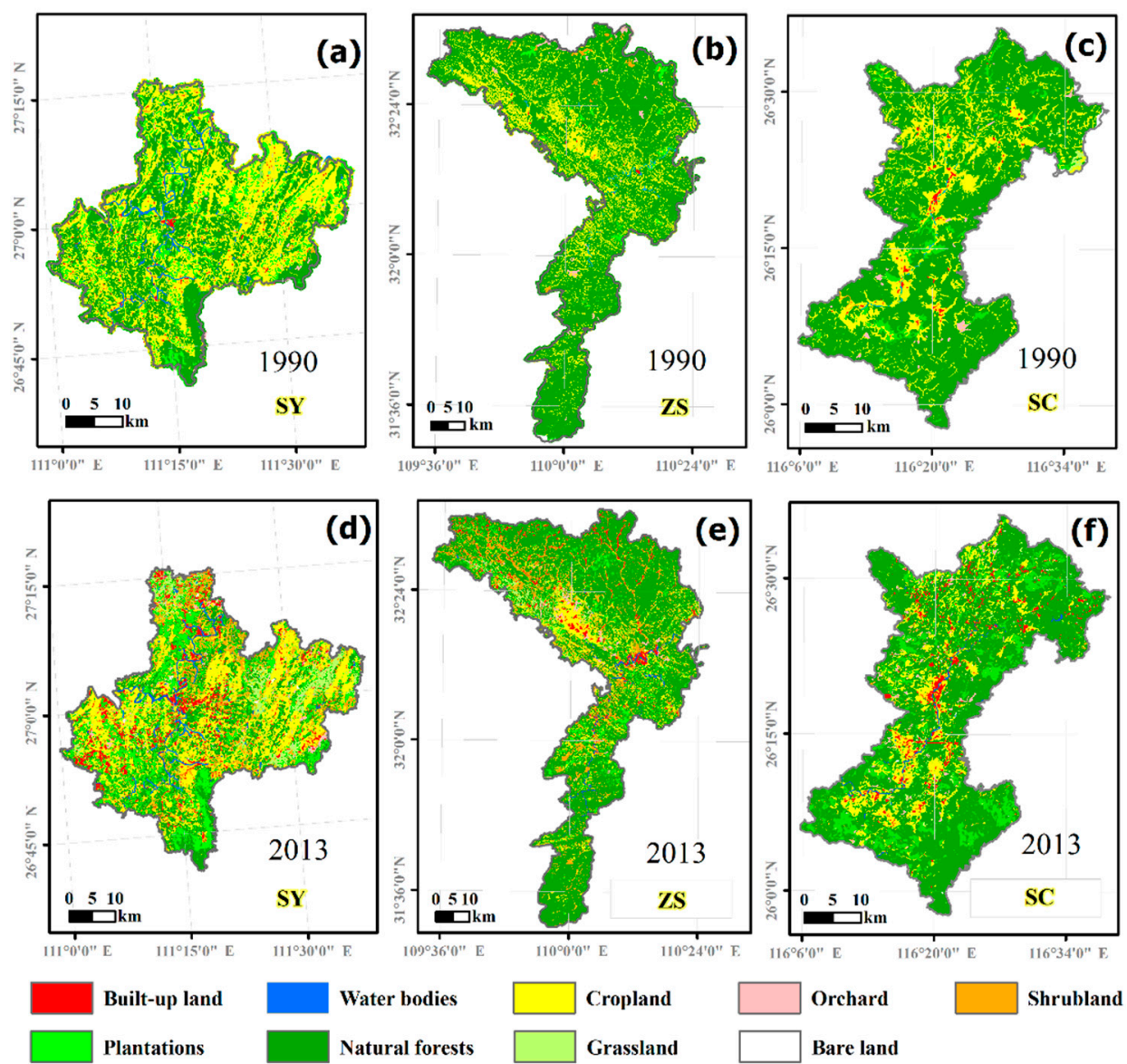

Figure 3. Distribution of land use types in the study area (a-c) in 1990, and (d-f) in 2013.

Table 3. The land use types and proportions in the study areas.

\begin{tabular}{|c|c|c|c|c|c|c|c|c|c|c|c|c|}
\hline \multirow{3}{*}{$\begin{array}{l}\text { Land } \\
\text { Use } \\
\text { Types }\end{array}$} & \multicolumn{4}{|c|}{ SY } & \multicolumn{4}{|c|}{ ZS } & \multicolumn{4}{|c|}{ SC } \\
\hline & \multicolumn{2}{|c|}{1990} & \multicolumn{2}{|c|}{2013} & \multicolumn{2}{|c|}{1990} & \multicolumn{2}{|c|}{2013} & \multicolumn{2}{|c|}{1990} & \multicolumn{2}{|c|}{2013} \\
\hline & $\begin{array}{c}\text { Area } \\
\left(\mathrm{km}^{2}\right)\end{array}$ & $\begin{array}{c}\text { Percent } \\
(\%)\end{array}$ & $\begin{array}{c}\text { Area } \\
\left(\mathbf{k m}^{2}\right)\end{array}$ & $\begin{array}{l}\text { Percent } \\
(\%)\end{array}$ & $\begin{array}{c}\text { Area } \\
\left(\mathbf{k m}^{2}\right)\end{array}$ & $\begin{array}{l}\text { Percent } \\
\text { (\%) }\end{array}$ & $\begin{array}{c}\text { Area } \\
\left(\mathbf{k m}^{2}\right)\end{array}$ & $\begin{array}{l}\text { Percent } \\
(\%)\end{array}$ & $\begin{array}{c}\text { Area } \\
\left(\mathrm{km}^{2}\right)\end{array}$ & $\begin{array}{c}\text { Percent } \\
(\%)\end{array}$ & $\begin{array}{c}\text { Area } \\
\left(\mathrm{km}^{2}\right)\end{array}$ & $\begin{array}{c}\text { Percent } \\
(\%)\end{array}$ \\
\hline GL & 3.36 & 0.17 & 147.86 & 7.39 & 2.41 & 0.07 & 102.17 & 2.85 & 6.82 & 0.44 & 6.9 & 0.44 \\
\hline CL & 885.45 & 44.25 & 589.08 & 29.44 & 775.85 & 21.62 & 373.48 & 10.41 & 324.92 & 20.73 & 212.01 & 13.53 \\
\hline SL & 4.03 & 0.20 & 207.77 & 10.38 & 20.57 & 0.57 & 390.96 & 10.9 & 1.35 & 0.09 & 13.78 & 0.88 \\
\hline $\mathrm{OC}$ & 6.04 & 0.30 & 27.81 & 1.39 & 35.98 & 1.00 & 36.78 & 1.03 & 10.49 & 0.67 & 20.74 & 1.32 \\
\hline BUL & 23.34 & 1.17 & 147.28 & 7.36 & 5.02 & 0.14 & 97.39 & 2.71 & 10.27 & 0.66 & 51.34 & 3.28 \\
\hline BL & 0.46 & 0.02 & 3.62 & 0.18 & 0.58 & 0.02 & 0.16 & 0.00 & 0.58 & 0.04 & 24.52 & 1.56 \\
\hline $\mathrm{PT}$ & 227.32 & 11.36 & 379.67 & 18.97 & 56.91 & 1.59 & 275.15 & 7.67 & 55.76 & 3.56 & 188.91 & 12.05 \\
\hline $\mathrm{NF}$ & 813.87 & 40.67 & 463.74 & 23.18 & 2669.73 & 74.41 & 2274.03 & 63.38 & 1152.36 & 73.52 & 1036.78 & 66.15 \\
\hline WB & 37.12 & 1.86 & 34.18 & 1.71 & 20.77 & 0.58 & 37.7 & 1.05 & 4.85 & 0.31 & 12.43 & 0.79 \\
\hline Total & 2001.01 & 100 & 2001.01 & 100 & 3587.81 & 100.00 & 3587.81 & 100 & 1567.4 & 100 & 1567.4 & 100 \\
\hline
\end{tabular}

From the landscape scale, the LPI, MPS, and IJI of the three counties all showed a decreasing trend during the study period. This suggests that the landscape pattern in all three counties had become more fragmented and heterogeneous. Among the three counties, SY had the largest decrease in LPI, which decreased from $11.18 \%$ to $5.45 \%$, with a decrease of $51.25 \%$, indicating that the SY big patches decreased the most obviously. The MPS of SC decreased from $19.52 \%$ to $15.79 \%$ and $19.11 \%$, respectively, and the increase in patch 
fragmentation was sharp. The PAFRAC and COHESION of the three counties showed an increasing trend, indicating that the shapes of land use patches in the three counties had become more complex during the study period. The direct distance between the same type of patch became closer. The aggregation of the landscape pattern had increased (Table 4).

Table 4. Landscape indices of Shaoyang (SY), Zhushan (ZS), and Shicheng (SC) counties.

\begin{tabular}{|c|c|c|c|c|c|c|c|c|c|c|}
\hline \multirow{2}{*}{ Counties } & \multicolumn{2}{|c|}{ LPI (\%) } & \multicolumn{2}{|c|}{ MPS (ha) } & \multicolumn{2}{|c|}{ PAFRAC } & \multicolumn{2}{|c|}{ IJI (\%) } & \multicolumn{2}{|c|}{ COHESION (\%) } \\
\hline & 1990 & 2013 & 1990 & 2013 & 1990 & 2013 & 1990 & 2013 & 1990 & 2013 \\
\hline SY & 11.18 & 5.45 & 8.95 & 6.71 & 1.18 & 1.29 & 78.95 & 74.95 & 97.89 & 98.01 \\
\hline ZS & 33.56 & 30.64 & 9.59 & 7.74 & 1.27 & 1.32 & 68.95 & 61.95 & 98.99 & 99.62 \\
\hline SC & 55.26 & 52.4 & 19.52 & 15.79 & 1.2 & 1.26 & 69.4 & 61.4 & 98.87 & 99.74 \\
\hline
\end{tabular}

Although the changes in the landscape metrics of different land use types in the three counties were different, the change trend was basically the same from 1990 to 2013. During the study period, the PLAND, LPI, MPS, and COHESION of PL, BUL, GL, SL, and OC all increased, while PAFRAC and IIJ decreased. Among them, the change of BUL and SL were more obvious. The results showed that the landscape heterogeneity of PL, BUL, GL, SL, and OC decreased, and their spatial aggregation and connectivity increased. On the contrary, the landscape patterns of NF, CL, and WB showed the trend of fragmentation in the period (Table 5).

Table 5. Landscape indices of land use types in Shaoyang (SY), Zhushan (ZS), and Shicheng (SC) counties.

\begin{tabular}{|c|c|c|c|c|c|c|c|c|c|c|c|c|c|}
\hline \multirow{2}{*}{\multicolumn{2}{|c|}{$\begin{array}{l}\text { Counties' Land } \\
\text { Use Types }\end{array}$}} & \multicolumn{2}{|c|}{ PLAND (\%) } & \multicolumn{2}{|c|}{ LPI (\%) } & \multicolumn{2}{|c|}{ MPS (ha) } & \multicolumn{2}{|c|}{ PAFRAC } & \multicolumn{2}{|c|}{ IJI (\%) } & \multicolumn{2}{|c|}{ COHESION (\%) } \\
\hline & & 1990 & 2013 & 1990 & 2013 & 1990 & 2013 & 1990 & 2013 & 1990 & 2013 & 1990 & 2013 \\
\hline \multirow{9}{*}{ SY } & NF & 30.61 & 23.03 & 2.45 & 2.03 & 6.31 & 5.83 & 1.21 & 1.31 & 74.62 & 73.61 & 97.23 & 96.81 \\
\hline & PT & 16.11 & 18.84 & 3.58 & 1.02 & 5.98 & 6.49 & 1.03 & 1.01 & 71.25 & 69.22 & 96.65 & 96.78 \\
\hline & BUL & 5.12 & 7.34 & 0.32 & 0.41 & 6.41 & 8.61 & 1.21 & 1.3 & 78.25 & 77.16 & 94.23 & 95.3 \\
\hline & CL & 35.98 & 29.71 & 6.21 & 5.45 & 34.12 & 33.32 & 1.36 & 1.32 & 79.25 & 81.72 & 99.56 & 99.38 \\
\hline & WB & 2.95 & 1.72 & 1.06 & 1.07 & 16.21 & 15.19 & 1.36 & 1.35 & 77.9 & 78.5 & 98.92 & 98.81 \\
\hline & GL & 3.21 & 7.45 & 1.63 & 1.65 & 1.23 & 5.26 & 1.27 & 1.29 & 77.98 & 78.38 & 97.68 & 98.06 \\
\hline & SL & 5.12 & 10.34 & 0.36 & 0.38 & 1.48 & 3.28 & 1.32 & 1.31 & 74.45 & 73.73 & 93.62 & 94.71 \\
\hline & $\mathrm{OC}$ & 0.79 & 1.39 & 0.15 & 0.22 & 5.98 & 7.35 & 1.25 & 1.28 & 83.98 & 84.08 & 93.98 & 94.04 \\
\hline & $\mathrm{BL}$ & 0.11 & 0.18 & 0.01 & 0.02 & 1.08 & 3.41 & 1.15 & 1.14 & 86.54 & 85.94 & 94.32 & 93.49 \\
\hline \multirow{9}{*}{ ZS } & NF & 69.97 & 63.92 & 29.32 & 30.64 & 35.23 & 33 & 1.36 & 1.38 & 73.21 & 67.05 & 99.89 & 99.88 \\
\hline & PT & 5.62 & 7.46 & 2.46 & 0.23 & 6.45 & 7.06 & 1.21 & 1.17 & 49.25 & 47.82 & 94.36 & 95.88 \\
\hline & BUL & 1.31 & 2.71 & 0.09 & 0.11 & 6.32 & 8.13 & 1.23 & 1.3 & 78.21 & 77.19 & 92.15 & 93.94 \\
\hline & CL & 12.02 & 10.41 & 2.32 & 1.93 & 12.78 & 8.7 & 1.34 & 1.31 & 70.21 & 68.91 & 97.69 & 96.97 \\
\hline & WB & 2.32 & 1.06 & 0.62 & 0.35 & 25.65 & 21.5 & 1.38 & 1.43 & 76.23 & 77.28 & 98.56 & 98.01 \\
\hline & GL & 2.1 & 2.86 & 0.98 & 0.41 & 1.02 & 4.83 & 1.31 & 1.37 & 64.2 & 66.43 & 96.52 & 96.61 \\
\hline & SL & 6.13 & 10.55 & 0.75 & 0.61 & 1.42 & 2.04 & 1.34 & 1.37 & 51.86 & 53.63 & 92.98 & 93.16 \\
\hline & OC & 0.52 & 1.03 & 0.09 & 0.11 & 5.79 & 7.63 & 1.26 & 1.29 & 79.65 & 79.53 & 95.32 & 96.99 \\
\hline & BL & 0.01 & 0.01 & 0.01 & 0.01 & 3.2 & 5.48 & 1.14 & 1.15 & 62.13 & 57.92 & 93.25 & 92.42 \\
\hline \multirow{9}{*}{ SC } & NF & 68.9 & 66.35 & 51.89 & 52.4 & 63.12 & 53.91 & 1.34 & 1.31 & 74.87 & 74.4 & 99.87 & 99.93 \\
\hline & PT & 7.52 & 11.98 & 3.22 & 0.77 & 15.03 & 16.05 & 1.27 & 1.20 & 43.21 & 36.75 & 97.21 & 97.95 \\
\hline & BUL & 2.58 & 3.25 & 0.18 & 0.24 & 5.78 & 7.51 & 1.19 & 1.25 & 62.63 & 59.74 & 92.16 & 93.76 \\
\hline & CL & 16.98 & 13.54 & 1.21 & 0.81 & 11.98 & 7.95 & 1.32 & 1.29 & 63.21 & 58.28 & 98.23 & 97.16 \\
\hline & WB & 1.35 & 0.8 & 0.32 & 0.3 & 19.62 & 13.88 & 1.42 & 1.4 & 69.12 & 65.04 & 98.12 & 97.54 \\
\hline & GL & 1.26 & 1.79 & 0.01 & 0.02 & 1.13 & 2.42 & 1.19 & 1.23 & 58.32 & 55.46 & 89.12 & 85.82 \\
\hline & SL & 0.21 & 0.8 & 0.02 & 0.01 & 0.69 & 1.03 & 1.26 & 1.31 & 39.63 & 37.09 & 91.12 & 88.37 \\
\hline & $\mathrm{OC}$ & 1.12 & 1.32 & 0.03 & 0.04 & 5.98 & 7.22 & 1.19 & 1.24 & 59.13 & 58.51 & 91.18 & 92.32 \\
\hline & BL & 0.08 & 0.16 & 0.01 & 0.01 & 1.03 & 2.69 & 1.17 & 1.21 & 63.13 & 64.4 & 83.12 & 84.38 \\
\hline
\end{tabular}

During the study period, MPS of NF in SY decreased from 6.31 ha in 1990 to 5.83 ha in 2013. Compared with ZS and SC, the landscape pattern of NF in SY was the most fragmented in both 1990 and 2013. The patch shape of NF in SY was also the simplest and the connectivity was the lowest. Compared with the other two counties, the landscape pattern of PL in SY was always the most fragmented. In 1990, the MPS of PT in SY was only $39.79 \%$ of SC. In 2013, the MPS of PL in SY was only $40.43 \%$ of SC. On the contrary, the 
PLAND, LPI, MPS, and COHESION of BUL and CL both were the largest in SY compared with ZS and SC. The MPS of CL in SY was 1.75 times of ZS and 1.91 times of SC. This shows that the landscape aggregation and connectivity of BUL and CL in the SY county were increased, while the forest land (NF and PT) was seriously fragmented (Table 5).

\subsection{Landscape Patterns of Land Use Types along Altitude Gradients}

The NF and CL accounted for more than half of the overall areas in II in 2013 (Figure 4). The proportion of NF and CL in II were $54.25 \%$ in SY, $55.91 \%$ in ZS, and $79.54 \%$ in SC. The PT were much larger in the II, III, and IV than in the other sub-regions (I and V). The NF increased from I $(6.27 \%-55.77 \%)$ to $\mathrm{V}(84.02 \%-97.28 \%)$.

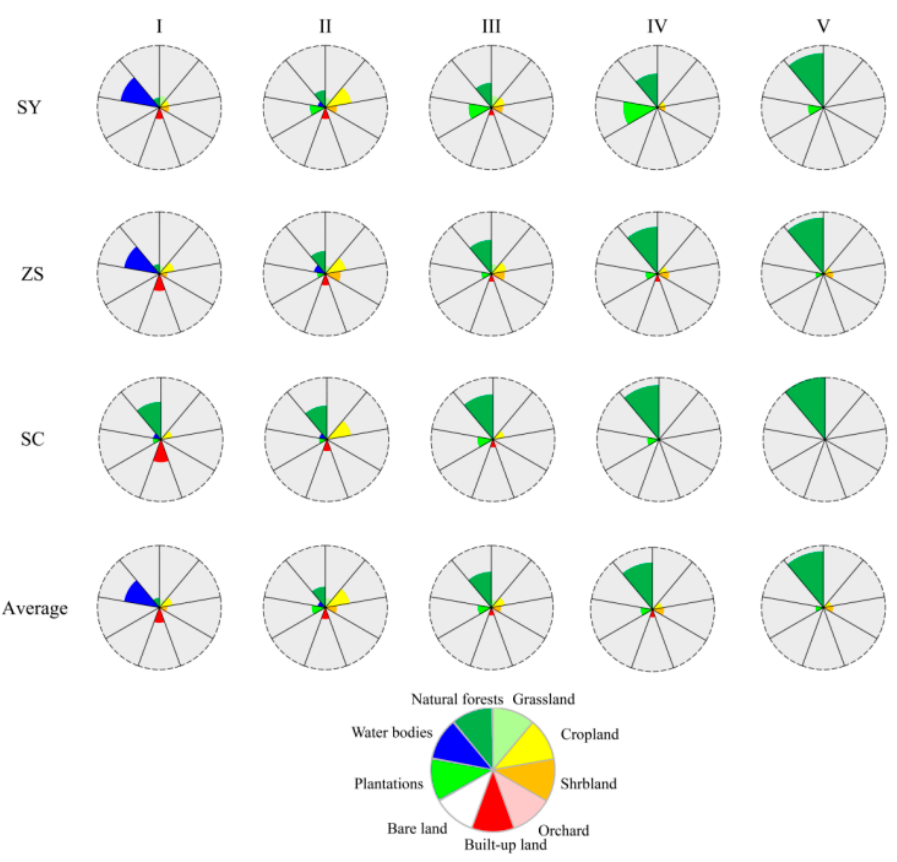

Figure 4. I (0-100 m), II (100-250 m), III (250-500 m), IV (500-1000 m), and V (1000-2500 m) represent five sub-regional divisions by elevation in Shaoyang (SY), Zhushan (ZS), and Shicheng (SC) counties in 2013. The flower diagrams illustrate the land use percentages of five sub-regions with different elevations by petal length. Each flower represents the percentage of land use types for one sub-region in SY, ZS, and SC.

The WB was mainly concentrated in I (more than 50\%) in the three counties. The GL and SL were evenly distributed. The BUL increased from I $(16.72 \%)$ to II $(8.45 \%)$, and decreased to $\mathrm{V}(0.18 \%)$ in the three counties (Figure 4$)$. The CL increased from I $(13.22 \%)$ to II $(32.75 \%)$ and decreased to V $(2.58 \%)$. The NF increased from I (6.43\%) to V $(87.58 \%)$. The PT were concentrated in II (12.34\%), III (14.04\%), and IV (10.76\%), and accounted for $4.33 \%$ in the sum of I and V.

The LPI were the smallest and PAFRAC was the largest in II and III than in the other sub-regions (Figure 5). The MPS tended to decrease with increasing altitude in the three counties, in II and III, than the other sub-regions. The IJI increased from I to II, and decreased from II to III. The changes of COHESION basically showed a tendency to increase with altitude.

Along the altitude gradients, the PLAND of PT increased from I to IV, and then decreased to V in SY and ZS. The PT had the largest LPI value at $15.79 \%$ in III, and $11.29 \%$ in IV in SY, however, it was only $<1 \%$ in ZS and $<2 \%$ in SC, respectively. Overall, the IJI of PT decreased from I to V. The MPS of PT in I (0.23-0.54 ha) and II (1.05-3.3 ha) were the lowest compared with other land use types in the three counties. The MPS was bigger in NF than in PT, except for IV of SY. The COHESION increased from I to IV, and then decreased to V in PT, being lower than that in NF (Figure 6). 

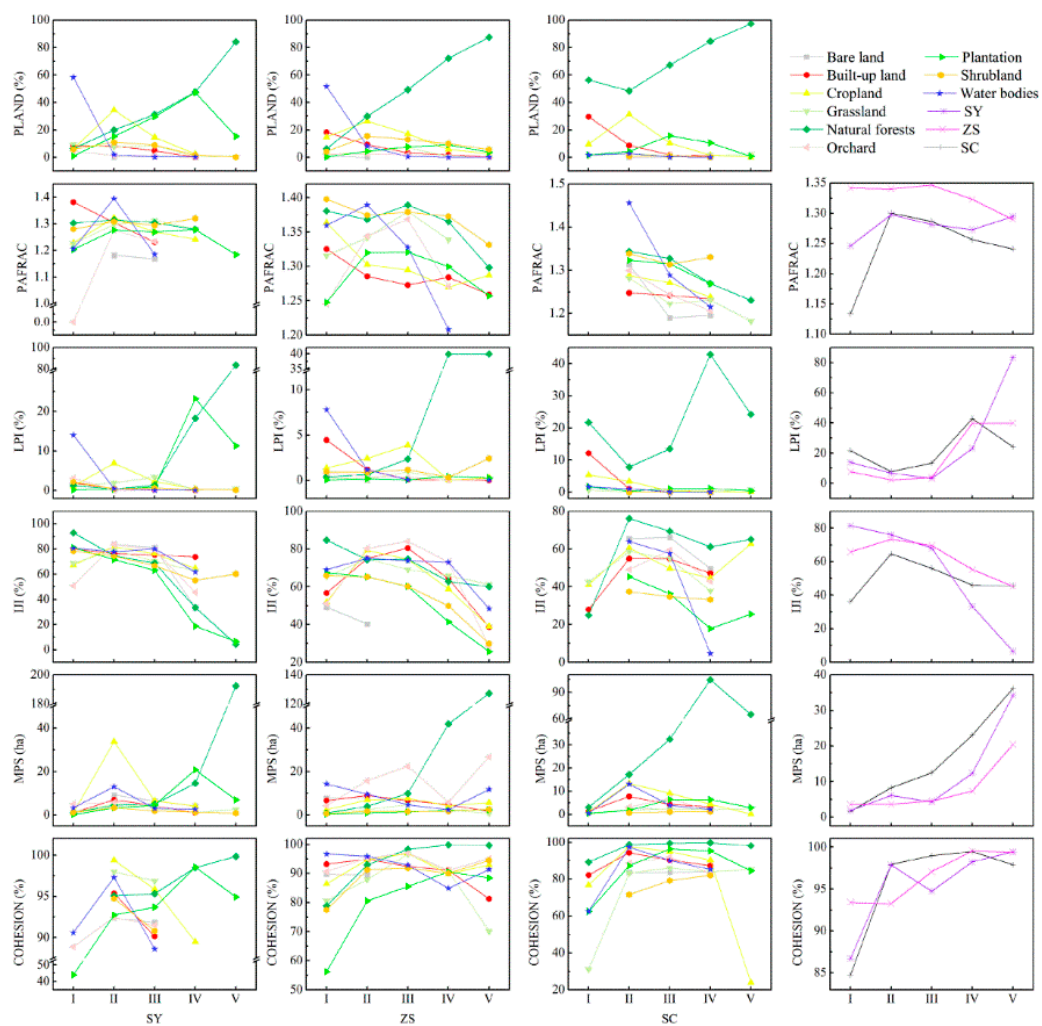

Figure 5. Variations and average trends of landscape indices along the altitude gradients in Shaoyang (SY), Zhushan (ZS), and Shicheng (SC) counties in 2013.
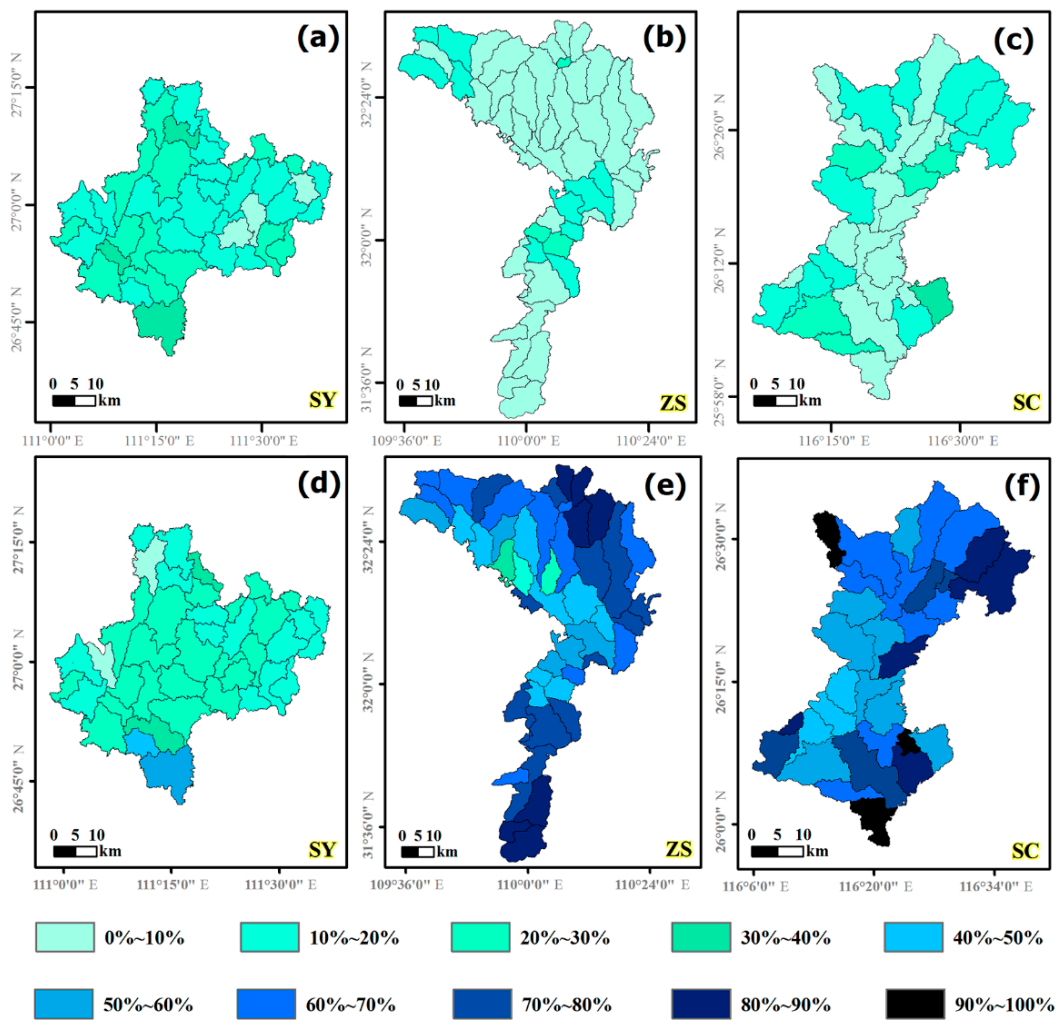

$30 \% \sim 40 \%$

$40 \% \sim 50 \%$

Figure 6. Percentage of plantations and natural forests in 2013 at the watershed scale (number of sub-basins, $n=35,42$, and 32 in SY, ZS, and SC). (a-c) Percentages of plantations in SY, ZS, and SC. (d-f) Percentages of natural forests in SY, ZS, and SC. 


\subsection{Landscape Patterns of Land Use Types at the Sub-Basin Level}

According to the distribution of the land use types in the watersheds, the proportion of NF in the three counties was far more than the PT (Figure 7). In SY, PT accounted for $10-30 \%$ of the land area with a major fraction in the northwest and southern portions of the county, and NF accounted for $20-40 \%$, with a major fraction in the central and southern portions of the county. In ZS, the area of PT typically accounted for $0-10 \%$, while NF accounted for more than $40 \%$. In SC, the proportion of PT accounted for $0-20 \%$ in the central region, and $10-20 \%$ in the surrounding area, while the NF typically accounted for more than $60 \%$.

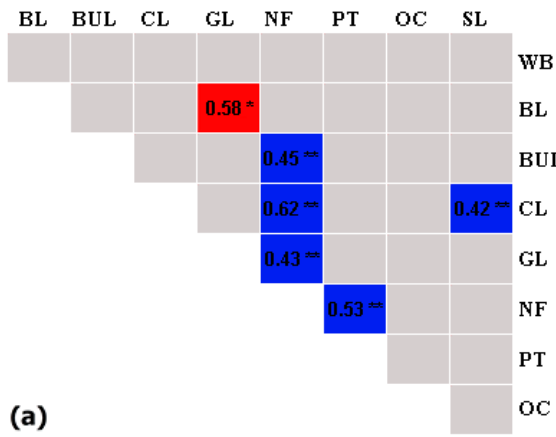

BL BUL CL GL NF PT OC $\quad$ SL
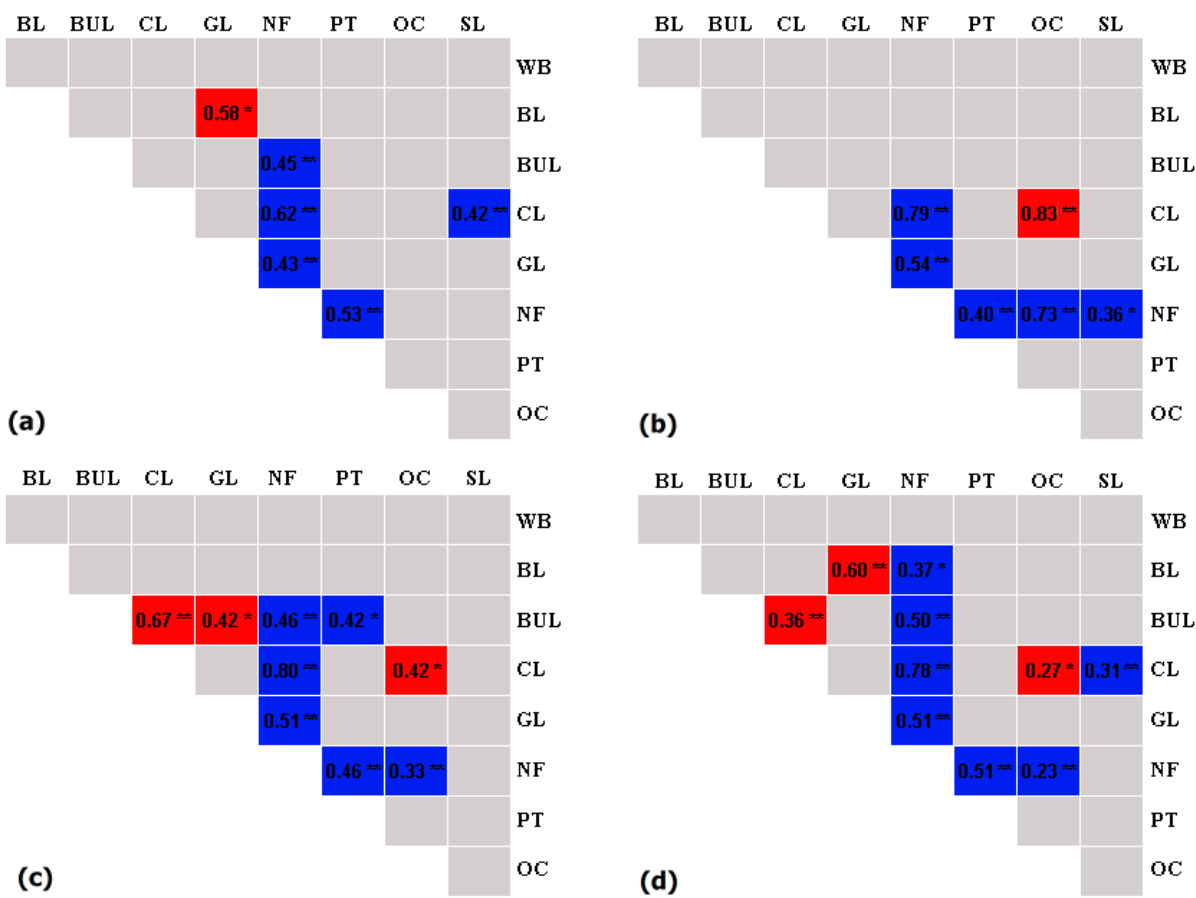

Figure 7. Pairwise relationships between areas of land use types at the watersheds scale in 2013. (a) The relationship of land use types in SY, (b) the relationship of land use types in ZS, (c) the relationship of land use types in SC, and (d) the relationship of land use types. Blue represents negative relationships and red represents positive relationships. White represents relationships with no established inter-relationship. The data in the frame represents the correlation coefficients between land use types. * Means that $p$ less than $0.05 ;{ }^{* *}$ means that $p$ less than 0.01 . BL refers to bare land, BUL to built-up land, CL to cropland, GL to grassland, NF to natural forests, PT to plantations, OC to orchard, SL to shrubland, and WB to waterbodies.

\subsection{Correlations between Land Use Types}

According to the correlation analysis of land use in different watersheds in 2013, the NF were negatively correlated with CL, PT, and GL $(p<0.01)$ in three counties (Figure 7). $\mathrm{NF}$ and BUL showed a significant negative correlation $(p<0.01)$ in SY and SC, but not in ZS. The OC and CL were significantly positively related in ZS $(p<0.01)$ and SC $(p<0.05)$. For all data combined in the three counties, there were negative correlations of NF with BL, BUL, $\mathrm{CL}, \mathrm{PT}, \mathrm{GL}$, and $\mathrm{OC}$, and a negative correlation between $\mathrm{SL}$ and $\mathrm{CL}$, but positive correlations between CL and BUL, between GL and BUL, and between OC and CL (Figure 7).

\section{Discussion}

\subsection{Characteristics of Forest Landscape Patterns}

Our results clearly demonstrated that the landscape patterns of the study area were more fragmented in contrast to most counties of Southern and Northern China [34-36]. This is because the study areas were located in the middle reaches of the Yangtze River as 
the central parts of China where there was a longer developmental history, and the natural landscape was more strongly influenced by anthropogenic activities compared with most other areas in China $[16,37,38]$. This also implies that it is a harder task to improve the quality of plantation stands and to raise the level of ecosystem services across this region. In this context, there were two prominent features of forest landscape patterns as follows.

First, the forests (including natural forests and plantations) were the dominant one among the land use types identified in this study (Table 3), albeit with high fragmentation and heterogeneity (Table 5). Compared with the landscape patterns of the forests in Taishan Mountain, Qilian Mountain, and the middle Qinling Mountain, etc. across China, the forests in the study area were more fragmented [19,39-42]. Concurrently, the forest landscape of SY was also more fragmented than some of the other mountainous regions of the world $[43,44]$. This was revealed in recent years, although many plantations have been established and the forest coverage appears to be improved. People took for granted that a manmade ecological environment could be recovered, but there could be a tremendous gap between the landscape pattern and the original ecological environment [22,45].

Second, the PT were more fragmented and heterogeneous than the NF, which suggested that plantations were more strongly controlled in this region. This phenomenon was consistent with the landscape patterns of plantations in the Loess Plateau of China [38]. Fragmented forest landscapes lead to profound impacts on forest structures and compositions, causing changes in forest biodiversity and ecosystem functionality [23]. This can be confirmed by species diversity, soil quality, and fine root biomass, etc. in the soil profile of PT, which are relatively lower than NF [46,47].

\subsection{Effects of Anthropogenic Disturbance on Land Use Types}

From the perspective of socioeconomic development of the three counties, the urbanization level of SY, ZS, and SC existed at different levels. SY had the largest proportion of CL (29.36\%) and BUL (7.44\%), as well as a high GDP and population density compared with ZS and SC. The landscape pattern of SY was relatively fragmented and heterogeneous. The MPS of NF in SY was quite smaller than ZS and SC, which indicated that, presumably, anthropogenic activities, global warming, vegetation degradation, etc., strongly impacted the landscape patterns, and likely made the forests more fragmented.

Although various counties had different landscape characteristics, the change trends of the elevation related landscape patterns in the three counties were basically the same. With the increase in elevation, the number of large patches increased, the connectivity increased, and the patch shape gradually became simpler. Land use showed typical zonal distribution with elevation, and the proportion of NF steadily increased with altitude, however, the PT had a primary centralized distribution at $100-1000 \mathrm{~m}(>84.13 \%)$ in the three counties. The PAFRAC, MPS, and COHESION of PT also peaked from 100 to 1000 $\mathrm{m}$. The homogeneity and connection of PT at the 100-1000 m elevation range were higher than at other altitudes, but still significantly lower than that of NF.

This indicates that there was still a gap of landscape patterns between the reconstructed forests and natural forests following anthropogenic destruction. It can also be proven that natural reserves and forest parks were always distributed at a relatively high altitude, where their species diversity and ecological aesthetic landscape value are relatively high [48]. The IJI of PT was the lowest of all the land use, indicating that PT were influenced by geographic distributed or artificial management, and their distribution was the most typical zonal distribution among all land use types.

\subsection{Important Implications of the Results}

Ecosystem services provided by forests are closely associated with both the total areas and distribution patterns [49]. For example, under the isolation effect of habitat patches, the migration and colonization of biological populations are limited [50,51]. The population of the habitat patches is smaller, and the gene exchange of the population is limited [52]. Landscape pattern changes can also be implicated in relation to the alteration 
of soil nutrients, hydrological cycles, and microclimates in the watershed [53]. Therefore, when implementing plantations, landscape patterns should be taken into account to avoid the negative effects brought about by fragmentation and habitat isolation.

Based on the geographical locations of three counties and the landscape patterns of forest vegetation, our results demonstrated the potential implications of natural resource conservation in this region where there has been a rapid socioeconomic development. First, it is essential to balance the economic development and natural protection for counties such as Shicheng and Zhushan. Our results revealed that there was a higher forest coverage (Figure 3 and Table 3), but a less developed economy in Shicheng and Zhushan counties [34-36]. However, the local people and governments have strong desires to develop the economy through the use of natural resources, where the simplest and fastest strategies are to cut forests to sell timber and to develop economic plantations, such as orange, bamboo, conifers, etc., to substitute protection forests for increasing the income of the local people. In order to mitigate such conflicts between economic development and environmental conservation in these areas, one feasible and efficient strategy is to implement an ecological compensation policy [5].

Second, our results clearly showed that the forest coverage was from $40 \%$ in SY to $80 \%$ in SC at the county scale, which was much higher than the mean value at the national level $(21 \%)$, however, most of the forests were in remote and steep-sloped areas that were highly fragmented and uneven (Table 4 and Figure 5). This results in a reduction in the actual ecosystem services of forests, in particular, water and soil conservation, biodiversity, and recreation $[46,47]$. Thus, there are two silvicultural measures to be stressed in forest management for this region. One is to manage plantations in terms of nature-based orientation management philosophy such that plantation stands might be translated to high ecological benefit forest ecosystems $[54,55]$. This measure has been widely recognized in China $[32,56]$. Across the study areas, evergreen and deciduous broadleaf mixed forests are the zonal vegetation, with dominant tree species such as Cinnamomum spp., Quercus spp., Schima spp., and Castanopsis spp. (Figure 2d-f) [3,57]. Thus, with this nature-based management strategy, local native broadleaf tree species should be introduced in the artificial coniferous plantations to form the broadleaf-dominant forests in this area.

One is to increase forest coverage by afforestation in bare lands and to establish shelter forests around fruit gardens and villages, as well as along roads and rivers. Across this region, there are strong conflicts between economic development (e.g., fruit garden, oil-tea camellia plantations, tourisms, animal breeding, etc.) and environment protection (e.g., afforestation, protection zone, etc.), and land areas for afforestation are limited [58]. In this context, one feasible way is to establish native-species plantations as the shelter forests around fruit gardens which are necessary both for ensuring a high yield for fruit production and for increasing ecological services. Furthermore, establishing shelter-belt or landscape forests around villages and along roads and rivers are also favorable for local citizens and necessary for governments according to the national development strategy $[59,60]$.

\section{Conclusions}

This paper analyzed the changes of land use types and landscape patterns at different scales in three typical counties in the middle reaches of the Yangtze River. The conclusions were as follows: (1) Compared with natural forests, plantations had smaller patches and a higher fragmentation degree; (2) the landscape patterns change of plantations were opposite to that of natural forests. The natural forests showed an increasing trend of fragmentation, while the plantations gathered from 1990 to 2013; (3) the areas of natural forests increased with the increase of altitude, the mean patch size increased and aggregation increased, while the areas of plantations reached the peak between 100 and $1000 \mathrm{~m}$; (4) the areas of natural forests were negatively correlated with land use types such as bare land, built-up land, cropland, plantations, grassland, and orchard. These results indicated that the natural forests were gradually fragmented, and the plantations patches were characterized with fragmentation and unevenness under strong anthropogenic dis- 
turbances, with strong disagreements in regards to the near natural patterns and functions that were desired in this region. In order to solve these problems, the middle reaches of the Yangtze River region should take corresponding forest management measures to improve the landscape connectivity of plantations and natural forests, not only to enhance the areas of forests, but also to pay attention to the quality.

Author Contributions: Conceptualization, Y.Y. and M.S.; methodology, B.W.; software, Y.Y.; validation, C.L.; formal analysis, Y.Y.; investigation, B.W.; resources, C.L., B.W., and M.S.; data curation, H.K.; writing—original draft preparation, Y.Y.; writing—review and editing, C.L., B.W., and M.S.; visualization, Y.Y.; supervision, M.S.; project administration, B.W.; funding acquisition, B.W. All authors have read and agreed to the published version of the manuscript.

Funding: This research was supported by the National Key R\&D Program of China (2017YFC0505501) and the Research Project of Chongqing Forestry Bureau (2020-10).

Institutional Review Board Statement: Not applicable.

Informed Consent Statement: Not applicable.

Data Availability Statement: Not applicable.

Conflicts of Interest: The authors declare no conflict of interest.

\section{Appendix A}

Table A1. Counties, land use types, and landscape metrics abbreviations.

\begin{tabular}{ccc}
\hline Types & Abbreviation & Content \\
\hline \multirow{3}{*}{ Counties } & SY & Shaoyang \\
& ZS & Zhushan \\
& SC & Shicheng \\
GL & Grassland \\
Land use types & CL & Cropland \\
& SL & Shrubland \\
& OC & Orchard \\
& BUL & Built-up land \\
& BL & Bare land \\
& WB & Water bodies \\
& PT & Plantations \\
NF & Natural forests \\
PAND & LPI & Percentage of Landscape \\
& MPS & Largest Patch Index \\
& PAFRAC & Mean Patch Area \\
& IJI & Area-Weighted Mean Fractal \\
& COHESION & Dimension Index \\
& & Interspersion Juxtaposition Index \\
\end{tabular}

\section{References}

1. Mori, S.A.; Boom, B.M.; Prance, G.T. Distribution patterns and conservation of eastern brazilian coastal forest tree species. Brittonia 1981, 33, 233. [CrossRef]

2. FAO. Global Forest Resources Assessment 2010; FAO Forestry Paper No. 163; UN Food and Agriculture Organization: Rome, Italy, 2010.

3. Dai, E.; Wang, X.; Zhu, J.; Xi, W. Quantifying ecosystem service trade-offs for plantation forest management to benefit provisioning and regulating services. Ecol. Evol. 2017, 7, 7807-7821. [CrossRef] [PubMed]

4. Kavanagh, K.; Stankey, G.; Boyle, J. The integration of planted and natural forests in a regional landscape. New For. 1999, 18, 97-109. [CrossRef]

5. Niu, X.; Wang, B.; Liu, S.; Liu, C.; Wei, W.; Kauppi, P.E. Economical assessment of forest ecosystem services in China: Characteristics and implications. Ecol. Complex. 2012, 11, 1-11. [CrossRef] 
6. Campagnaro, T.; Frate, L.; Carranza, M.L.; Sitzia, T. Multi-scale analysis of alpine landscapes with different intensities of abandonment reveals similar spatial pattern changes: Implications for habitat conservation. Ecol. Indic. 2017, 74, 147-159. [CrossRef]

7. Ren, Z.; He, X.; Zheng, H.; Wei, H. Spatio-Temporal Patterns of Urban Forest Basal Area under China's Rapid Urban Expansion and Greening: Implications for Urban Green Infrastructure Management. Forests 2018, 9, 272. [CrossRef]

8. Wu, C.; Wei, Y.D.; Huang, X.; Chen, B. Economic transition, spatial development and urban land use efficiency in the Yangtze River Delta, China. Habitat Int. 2017, 63, 67-78. [CrossRef]

9. Mairota, P.; Cafarelli, B.; Labadessa, R.; Lovergine, F.; Tarantino, C.; Lucas, R.M.; Nagendra, H.; Didham, R.K. Very high resolution Earth observation features for monitoring plant and animal community structure across multiple spatial scales in protected areas. Int. J. Appl. Earth Obs. Geoinf. 2015, 37, 100-105. [CrossRef]

10. Xiao, R.; Wang, G.; Zhang, Q.; Zhang, Z. Multi-scale analysis of relationship between landscape pattern and urban river water quality in different seasons. Sci. Rep. 2016, 6, 25250. [CrossRef]

11. Fan, Q.; Ding, S. Landscape pattern changes at a county scale: A case study in Fengqiu, Henan Province, China from 1990 to 2013. Catena 2016, 137, 152-160. [CrossRef]

12. Turner, M.G.; Donato, D.C.; Romme, W.H. Consequences of spatial heterogeneity for ecosystem services in changing forest landscapes: Priorities for future research. Landscape Ecol. 2013, 28, 1081-1097. [CrossRef]

13. Baldwin, J.B.D.; Weaver, K.; Schnekenburger, F.; Perera, A.H. Sensitivity of landscape pattern indices to input data characteristics on real landscapes: Implications for their use in natural disturbance emulation. Landscape Ecol. 2004, 19, 255-271. [CrossRef]

14. Tasser, E.; Tappeiner, U. Impact of land use changes on mountain vegetation. Appl. Veg. Sci. 2002, 5, 173-184. [CrossRef]

15. Wong, K.K. Diverse botanical communities in Yunnan and the Yangtze River Shelter Forest System. Geography 2005, 90, 288-293. [CrossRef]

16. Long, H.L.; Heilig, G.K.; Wang, J.; Li, X.B.; Luo, M.; Wu, X.Q.; Zhang, M. Land use and soil erosion in the upper reaches of the Yangtze River: Some socio-economic considerations on China's Grain-for-Green Programme. L. Degrad. Dev. 2006, 17, 589-603. [CrossRef]

17. Zhao, J.; Cao, Y.; Li, S.; Li, J.; Deng, Y.; Lu, G. Population genetic structure and evolutionary history of grass carp Ctenopharyngodon idella in the Yangtze River, China. Environ. Biol. Fishes 2011, 90, 85-93. [CrossRef]

18. FAO. Global Forest Resources Assessment 2015; FAO Forestry Paper No. 1; UN Food and Agriculture Organization: Rome, Italy, 2016.

19. Yang, Y.S.; Chen, G.S.; Lin, P.; Xie, J.S.; Guo, J.F. Fine root distribution, seasonal pattern and production in four plantations compared with a natural forest in Subtropical China. Ann. For. Sci. 2004, 61, 617-627. [CrossRef]

20. Chung, C.H. Thirty years of ecological engineering with Spartina plantations in China. Ecol. Eng. 1993, 2, 261-289. [CrossRef]

21. Song, W.; Liu, Y.; Tong, X. Newly sequestrated soil organic carbon varies with soil depth and tree species in three forest plantations from northeastern China. For. Ecol. Manag. 2017, 400, 384-395. [CrossRef]

22. Liu, M.; Tu, J. The position and role of Wuhan City in the regional economic macro-strategies of China. Chin. Geogr. Sci. 1998, 8 , 106-116. [CrossRef]

23. Shen, G.; Ibrahim Abdoul, N.; Zhu, Y.; Wang, Z.; Gong, J. Remote sensing of urban growth and landscape pattern changes in response to the expansion of Chongming Island in Shanghai, China. Geocarto Int. 2017, 32, 488-502. [CrossRef]

24. Li, Q.; Deng, X.I.; Huang, X.J.; Tian, D.L.; Fang, X. Study on carbon storage and distribution patterns of Pinus elliottii stand in rocky desertification area in Shaoyang county, Hunan province. J. Cent. South Univ. For. Technol. 2011, 31, 91-96. [CrossRef]

25. Xiang, Z.Y.; Deng, X.W.; Tian, D.L.; Zhou, X.; Liu, J.H.; Tang, L.Q. Effect of five vegetation restoration mode on physical and chemical properties of rocky desertification soil in Shaoyang County. J. Cent. South Univ. For. Technol. 2010, 30, 23-28. [CrossRef]

26. Yang, J.; Wang, Z.Z.; Yi, P.; Jin, G.; Hu, X.D. Spatial distribution of land consolidation projects and its correlation with the new countryside development program in Zhushan county. China Land Sci. 2014, 28, 62-70. (In Chinese)

27. Li, C.G.; Chen, M.Q.; Wang, Y.F.; Liao, C.F.; Huang, X.Y.; Pan, L.F. Development strategy of modern tobacco agriculture in Shicheng county based on SWOT. Chin. Agric. Sci. Bull. 2012, 28, 154-159.

28. Xie, H.J.; Huang, Y.L. Development status and suggestions of oil-tea camellia industry in Shicheng county. For. By-Prod. Spec. China 2017, 1, 85-87. (In Chinese)

29. United States Geological Survey. Remote Sensing Images. Available online: https:/ /www.usgs.gov/ (accessed on 17 April 2018 ).

30. Chinese Academy of Sciences. National Earth System Science Data Sharing Infrastructure. Available online: http://www.geodata. $\mathrm{cn} /$ (accessed on 17 April 2018).

31. Zhang, Y.; Song, C.; Zhang, K.; Cheng, X.; Band, L.E.; Zhang, Q. Effects of land use/land cover and climate changes on terrestrial net primary productivity in the Yangtze River Basin, China, from 2001 to 2010. J. Geophys. Res. Biogeosci. 2014, 119, 1092-1109. [CrossRef]

32. Yi, Y.; Zhao, Y.; Ding, G.; Gao, G.; Shi, M.; Cao, Y. Effects of Urbanization on Landscape Patterns in a Mountainous Area: A Case Study in the Mentougou District, Beijing, China. Sustainability 2016, 8, 1190. [CrossRef]

33. China's National Standard (GB/T 21010-2017). Current Land Use Condition Classification. Available online: http:/ /www.gov. cn/xinwen/2017-11/04/content_5237211.htm (accessed on 1 November 2017).

34. Hubei Province Bureau of Statistics. Hubei Statistical Yearbook 2014; China Statistics Press: Wuhan, China, 2014. (In Chinese)

35. Hunan Province Bureau of Statistics. Hunan Statistical Yearbook 2014; China Statistics Press: Changsha, China, 2014. (In Chinese)

36. Jiangxi Province Bureau of Statistics. Shanxi Statistical Yearbook 2014; China Statistics Press: Nanchang, China, 2014. (In Chinese) 
37. Ediger, L.; Chen, H.F. Upland China in Transition: The Impacts of Afforestation on Landscape Patterns and Livelihoods. Mt. Res. Dev. 2006, 26, 220-226. [CrossRef]

38. Zhou, D.; Zhao, S.; Zhu, C. The Grain for Green Project induced land cover change in the Loess Plateau: A case study with Ansai County, Shanxi Province, China. Ecol. Indic. 2012, 23, 88-94. [CrossRef]

39. Zhang, S.; Liu, X.H.; Jin, Q.; Li, J.H.; Jin, X.L.; Wei, F.W. The relationship between landscape pattern and the habitat of giant pandas on the southern slope of the middle Qinling Mountains. Acta Ecol. Sin. 2004, 24, 1950-1957.

40. Guo, L.; Xia, B.C.; Yu, S.X.; Xia, Z.F. Effect of anthropogenic disturbances on the temporal-spatial changes of landscape patterns at Taishan Mountain. Chin. J. Eco-Agric. 2006, 14, 236-239.

41. Wu, H.; Hu, X.; Sun, S.; Dai, J.; Ye, S.J.; Du, C.Y.; Chen, H.; Yu, G.L.; Zhou, L.; Chen, J. Effect of increasing of water level during the middle of dry season on landscape pattern of the two largest freshwater lakes of China. Ecol. Indic. 2020, 113, 106283. [CrossRef]

42. Yang, G.J.; Xiao, D.N.; Zhao, C.Z. GIS-based analysis on the forest landscape patterns in the Qilian mountain. Arid Zone Res. 2012, $21,27-32$.

43. Gonzalez-Avila, S.; Lopez-Leiva, C.; Bunce, R.G.H.; Elena-Rosselló, R. Changes and drivers in Spanish landscapes at the Rural-Urban Interface between 1956 and 2018. Sci. Total Environ. 2020, 714, 136858.1-136858.10. [CrossRef]

44. Sidiropoulou, A.; Karatassiou, M.; Galidaki, G.; Sklavou, P. Landscape pattern changes in response to transhumance abandonment on mountain Vermio (North Greece). Sustainability 2015, 7, 15652-15673. [CrossRef]

45. Rocha-Santos, L.; Pessoa, M.S.; Cassano, C.R.; Talora, D.C.; Orihuela, R.L.L.; Mariano-Neto, E.; Morante-Filho, J.C.; Faria, D.; Cazetta, E. The shrinkage of a forest: Landscape-scale deforestation leading to overall changes in local forest structure. Biol. Conserv. 2016, 196, 1-9. [CrossRef]

46. Tripathi, K.P.; Singh, B. Species diversity and vegetation structure across various strata in natural and plantation forests in Katerniaghat Wildlife Sanctuary, north India. Trop. Ecol. 2009, 50, 191-200.

47. Meng, L.Z.; Yang, X.D.; Martin, K.; Gan, J.M.; Liu, Y.H.; Gong, W.C. Movement patterns of selected insect groups between natural forest, open land and rubber plantation in a tropical landscape (southern Yunnan, SW China). J. Insect Conserv. 2016, 20, 363-371. [CrossRef]

48. Yu, D.; Han, S. Ecosystem service status and changes of degraded natural reserves-A study from the Changbai Mountain Natural Reserve, China. Ecosyst. Serv. 2016, 20, 56-65. [CrossRef]

49. Estoque, R.C.; Murayama, Y. Quantifying landscape pattern and ecosystem service value changes in four rapidly urbanizing hill stations of Southeast Asia. Landscape Ecol. 2016, 31, 1481-1507. [CrossRef]

50. Kowe, P.; Mutanga, O.; Dube, T. Advancements in the remote sensing of landscape pattern of urban green spaces and vegetation fragmentation. Int. J. Remote Sens. 2021, 42, 3797-3832. [CrossRef]

51. Ceballos, G.; Ehrlich, P.R.; Barnosky, A.D.; Garcia, A.; Pringle, R.M.; Palmer, T.M. Accelerated modern human-induced species losses: Entering the sixth mass extinction. Sci. Adv. 2015, 1, e1400253. [CrossRef]

52. Qiu, L.; Tao, T.T.; Han, S.R.; Yang, W.Y.; Luan, X.L.; Qiu, Y.N.; Liu, M.S.; Xu, C. Effects of local landscape fragmentation on species richness at a macroecological scale. Acta Ecol. Sin. 2017, 37, 7595-7603.

53. Chen, G.S.; Yang, Y.S.; Xie, J.S.; Guo, J.F.; Gao, R.; Qian, W. Conversion of a natural broad-leafed evergreen forest into pure plantation forests in a subtropical area: Effects on carbon storage. Ann. For. Sci. 2005, 62, 659-668. [CrossRef]

54. Hou, W.; Gao, J. Spatially Variable Relationships between Karst Landscape Pattern and Vegetation Activities. Remote Sens. 2020 12, 1134. [CrossRef]

55. Baishya, R.; Barik, S.K.; Upadhaya, K. Distribution pattern of aboveground biomass in natural and plantation forests of humid tropics in northeast India. Trop. Ecol. 2009, 50, 295-304.

56. Li, W.; Zheng, Z.; Li, T.; Zhang, X.; Wang, Y.; Yu, H.; He, S.; Liu, T. Effect of tea plantation age on the distribution of soil organic carbon fractions within water-stable aggregates in the hilly region of Western Sichuan, China. Catena 2015, 133, 198-205. [CrossRef]

57. Stumpf, F.; Goebes, P.; Schmidt, K.; Schindewolf, M.; Schönbrodt-Stitt, S.; Wadoux, A.; Xiang, W.; Scholten, T. Sediment reallocations due to erosive rainfall events in the Three Gorges Reservoir Area, Central China. L. Degrad. Dev. 2017, 28, 1212-1227. [CrossRef]

58. Zhang, W.G.; Wen, T.; Liu, L.Z.; Li, J.Y.; Gao, Y.; Zhu, D.; He, J.Z.; Zhu, Y.G. Agricultural land-use change and rotation system exert considerable influences on the soil antibiotic resistome in Lake Tai Basin. Sci. Total Environ. 2021, 771, 144848. [CrossRef] [PubMed]

59. Wang, X.H.; Kent, M.; Fang, X.F. Evergreen broad-leaved forest in Eastern China: Its ecology and conservation and the importance of resprouting in forest restoration. For. Ecol. Manag. 2007, 245, 76-87. [CrossRef]

60. Cao, L.; Liang, Y.; Wang, Y.; Lu, H. Runoff and soil loss from Pinus massoniana forest in southern China after simulated rainfall. Catena 2015, 129, 1-8. [CrossRef] 